\title{
17. LEAD AND STRONTIUM ISOTOPIC COMPOSITION OF SOME METALLIFEROUS AND PELAGIC SEDIMENTS AND BASALTS FROM THE GALAPAGOS MOUNDS AREA, DEEP SEA DRILLING PROJECT LEG 701
}

\author{
T. J. Barrett, ${ }^{2}$ Mineralogisches Institut, Universität Tübingen, Tübingen, Federal Republic of Germany
}

\section{INTRODUCTION}

In recent years, metalliferous sediments have been discovered overlying newly generated oceanic crust in the East Pacific, North Atlantic, Indian Ocean, Red Sea, Gulf of Aden, and elsewhere (e.g., Boström, 1973; Lalou et al., 1977; Bischoff, 1969; Boström and Fisher, 1971; Cann et al., 1977, respectively). Such material has also been recovered by drilling from sediments lying upon older oceanic crust (Boström et al., 1972, 1976; Horowitz and Cronan, 1976).

Hydrothermal circulation of seawater at a spreading ridge results in the leaching of $\mathrm{Fe}, \mathrm{Mn}$, and possibly other elements from the basaltic volcanic layer and their transport and discharge into ocean bottom waters, whereupon fine-grained $\mathrm{Fe}-\mathrm{Mn}$-rich precipitates form and settle into the ambient sediment (cf. Corliss, 1971; Dasch et al., 1971; Spooner and Fyfe, 1973; Bischoff and Dickson, 1975; Heath and Dymond, 1977; Corliss et al., 1979, Edmond et al., 1979). Mn-rich crusts have also been recovered from active ridges and are inferred to have formed in the vicinity of hydrothermal discharge areas (Scott et al., 1974; Moore and Vogt, 1976; Corliss et al., 1978; Hoffert et al., 1978).

The source of the trace elements in the metalliferous deposits is generally not clear. They may be derived from seawater by adsorption onto the precipitates or crusts, or from hydrothermal solutions which have leached them from the basalts. $\mathrm{Pb}$, however, can be used as a geochemical tracer because of the known isotopic compositional differences between oceanic basalts and seawater. Isotopic investigations of $\mathrm{Pb}$ in ferruginous sediments from the East Pacific have shown that it has been derived partly or mostly from a basaltic source (Bender et al., 1971; Dasch et al., 1971; Dymond et al., 1973).

In the present study, $\mathrm{Pb}$ isotopic analyses have been made of a suite of metalliferous sediments (nontronite, Mn-oxide crust, $\mathrm{Mn}-\mathrm{Fe}$-oxide mud), pelagic sediments, and basalts from the Galapagos mounds area. The main purposes of the $\mathrm{Pb}$ study were to determine the source or sources of $\mathrm{Pb}$ in the metalliferous sediments, and whether or not stratigraphic variations exist in the isotopic composition of $\mathrm{Pb}$ in the sediments.

\footnotetext{
${ }^{1}$ Honnorez, J. Von Herzen, R. P., et al., Init. Repts. DSDP, 70: Washington (U.S. Govt, Printing Office).

2 Present address: Department of Geology, University of Toronto, Toronto, Ontario, Canada, MSS IAI
}

In theory, ${ }^{87} \mathrm{Sr} /{ }^{86} \mathrm{Sr}$ ratios can also distinguish between seawater and basaltic sources, since they are characterized by very different ${ }^{87} \mathrm{Sr} /{ }^{86} \mathrm{Sr}$ ratios. However, those metalliferous sediments analyzed to date have ${ }^{87} \mathrm{Sr} /$ ${ }^{86} \mathrm{Sr}$ ratios in agreement with (or very close to) the ratio for modern seawater, indicating virtually no volcanic contribution (Dasch et al., 1971; Dymond et al., 1973; O'Nions et al., 1978). Nevertheless, a number of samples were analyzed to determine whether this is also the case for metalliferous sediment forming below, as opposed to at, the sediment/seawater interface.

\section{SAMPLES}

Twenty whole sediment samples were selected for $\mathrm{Pb}$ isotopic analysis; five of these were also analyzed for ${ }^{87} \mathrm{Sr} /{ }^{86} \mathrm{Sr}$ ratios. Seventeen of the twenty samples are from mounds sites, and three are from a nonmounds pelagic site (Hole 506B). Most mounds samples were from Holes 506 and 509B (six samples from each hole). Lithologically, the samples consist of 11 nontronites, 6 pelagic oozes, $2 \mathrm{Mn}$-oxide crusts, and $1 \mathrm{Mn}-\mathrm{Fe}$-oxide ooze. Thirteen of these samples, plus some additional ones, have also been analyzed for oxygen and hydrogen isotopes (Barrett et al., this volume).

With one exception, all nontronite samples are granular (granules typically $2-10 \mathrm{~mm}$ in diameter) and were taken from sections of the core where the nontronite was homogeneous in appearance; the exception is a sample from a transitional, nontronitic mud layer. Smear slides and XRD analyses indicate that the nontronitic samples are lithologically pure, containing less than $1 \%$ biogenic material and/or volcanic glass shards. Five of the six pelagic sediment samples are foraminifer nannofossil oozes containing about 5 to $10 \%$ clays. Of these five, one sample contains about $20 \%$ siliceous microfossils; the other four contain less than $10 \%$ siliceous microfossils. The sixth pelagic sample is of the oxidized brownish surface sediment which is present in a thin $(<50 \mathrm{~cm})$ layer at the top of all holes. The two Mnoxide crust samples each consist of several hard metallic plates (up to $20 \times 10 \times 5 \mathrm{~mm}$ in size); soft black porous sediment about $1 \mathrm{~mm}$ thick is commonly present on one or both sides of the plates. One sample is from the middle of the main unit of Mn crust recovered, near the top of Hole 509B; this unit consisted of 1.4 meters of Mnoxide crust fragments. The other sample is from a $30-\mathrm{cm}$ interval near the top of Hole 506C, over which Mn-oxide fragments are intermixed with nontronite granules, probably as a result of drilling disturbance. $\mathrm{Mn}-\mathrm{Fe}$ - 
oxide mud, present only in Hole 509B, occurs as two fairly well-defined layers about $10 \mathrm{~cm}$ thick near the top of the hole, just above and just below the main interval of Mn-oxide crust.

Five basalts were selected for $\mathrm{Pb}-, \mathrm{Sr}-$, and $\mathrm{O}$-isotopic analysis, four of which are from the Galapagos mounds area (Sites 506, 507, and 508). The other basalt sample is from older, nonmounds crust (Site 510) lying about 100 $\mathrm{km}$ north of the Galapagos mounds area. All samples are from depths in the crust of less than 15 meters, as a result of limited drill penetration in the basalts.

\section{ANALYTICAL TECHNIQUES}

In the case of sediments, 20 to $30 \mathrm{~g}$ of material were powdered using an agate mortar and pestle, and rinsed in distilled water. In the case of the basalts, 60- to $70-\mathrm{g}$ samples were broken into $\mathrm{cm}$-size fragments, rinsed in distilled water, crushed to sand size in a stainless steel mortar and pestle, then ground to a fine powder in an agate planetary ball mill.

$\mathrm{Pb}$ was extracted from whole-rock powder splits by dissolution followed by electrodeposition, following the technique of Arden and Gale (1974). Cathodic electrodeposition was carried out twice, prior to anodic electrodeposition, in order to ensure removal of all Fe prior to analysis. Samples were mounted on a single Re filament, using a silica gel-phosphoric acid activator, and the analyses were made on the Oxford 12-in. solid source mass spectrometer designed by Dr. N. H. Gale. $\mathrm{Pb}$ isotope data have been corrected for mass fractionation by comparison with results on standard NBS 981. Typical errors on $\mathrm{Pb}$ isotopic ratios are 0.1 to $0.15 \%(2 \delta)$.
Sr was extracted from powder splits by standard ion-exchange methods (cf. O'Nions and Pankhurst, 1973), and analyzed on a V.G. MM-30 mass spectrometer at Oxford. ${ }^{87} \mathrm{Sr} /{ }^{86} \mathrm{Sr}$ ratios have been normalized to a value of 0.70800 for the Eimer and Amend Sr standard. Typical errors on ${ }^{87} \mathrm{Sr} /{ }^{86} \mathrm{Sr}$ measurements are $0.01 \%$. Sr and $\mathrm{Rb}$ contents of basalts were determined by X-ray fluorescence. The errors in $\mathrm{Sr}$ concentration are not more than $\pm 5 \%$; the $\mathrm{Rb}$ data, however, should be considered semiquantitative because of the low concentration levels.

Oxygen isotopic measurements were carried out at the University of Tübingen, using splits of the whole-rock basalt powders analyzed for $\mathrm{Pb}$ and $\mathrm{Sr}$. Oxygen was extracted using the bromine pentafluoride procedure (Clayton and Mayeda, 1963). Oxygen isotopic compositions are reported using common $\delta$-notation relative to SMOW (Standard Mean Ocean Water). Routine reproducibility of $\delta^{18} \mathrm{O}$ values is $0.15 \%$.

\section{LEAD ISOTOPES}

\section{Results}

Lead isotopic ratios of the 20 sediment samples are given in Table 1, together with the $\mathrm{Sr}$ isotopic ratios of five of the samples. Table 2 lists the $\mathrm{Pb}-, \mathrm{Sr}-$, and $\mathrm{O}$-isotopic composition of the basalts. The $\mathrm{Pb}$ isotopic data are plotted in Figure 1. The most important aspects of these data are:

1) The sediments define approximately linear arrays, which result mainly from variation in the $\mathrm{Pb}$ isotopic

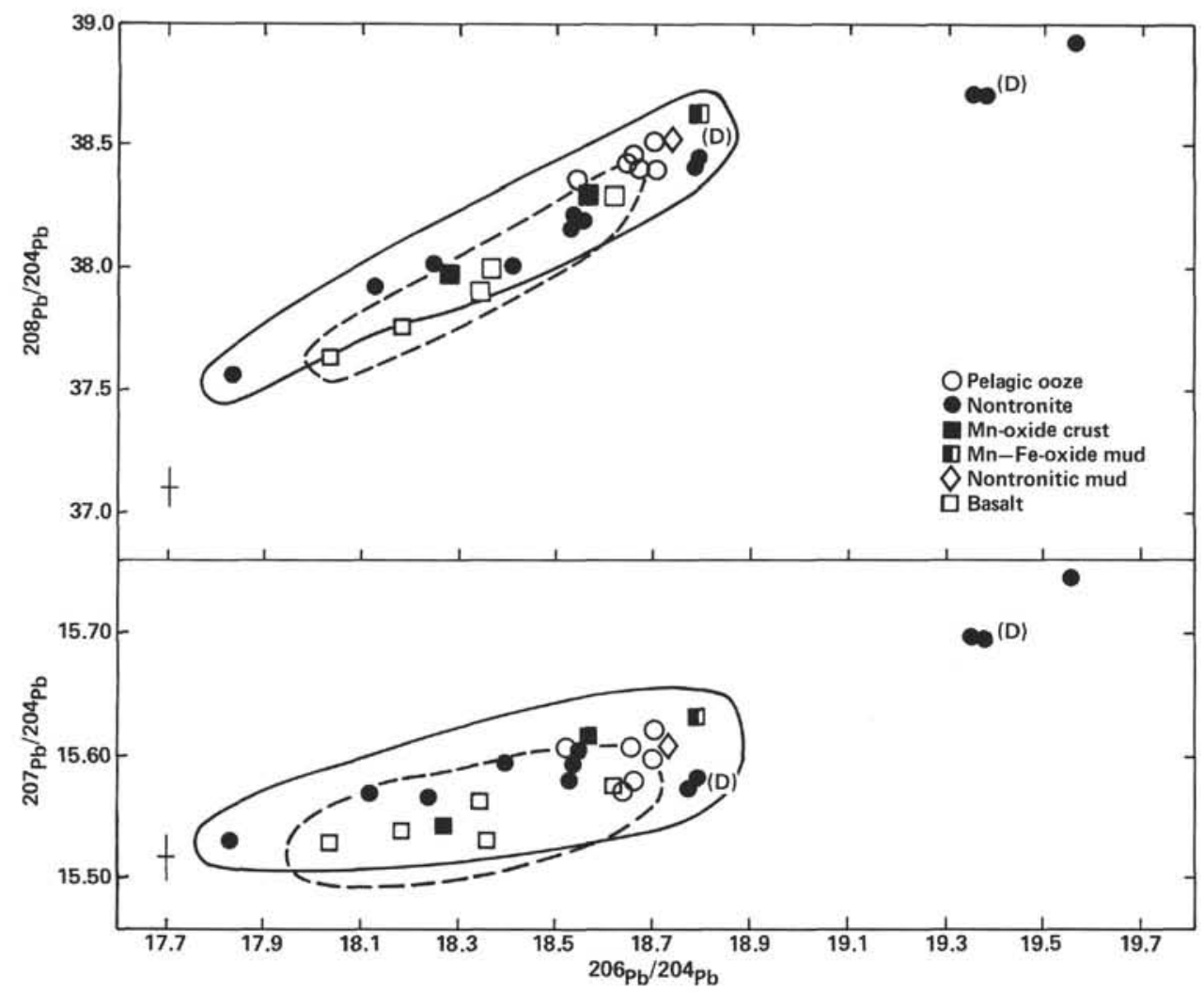

Figure $1 .{ }^{208} \mathrm{~Pb} /{ }^{204} \mathrm{~Pb}$ versus ${ }^{206} \mathrm{~Pb} /{ }^{204} \mathrm{~Pb}$ and ${ }^{207} \mathrm{~Pb} /{ }^{204} \mathrm{~Pb}$ versus ${ }^{206} \mathrm{~Pb} /{ }^{204} / \mathrm{Pb}$ for sediments and basalts from the Galapagos mounds area (Sites 506, 507, and 509). Solid lines enclose the sediment data arrays, and dashed lines the basalt data arrays (Table 1). Samples 12 and 17 were analyzed in duplicate (D). Samples 13 and 17 were not included in the sediment arrays because their $\mathrm{Pb}$ isotopic ratios are more radiogenic than seawater and mid-ocean ridge basalts (see text for discussion). Error bars give $2 \delta$ errors. 
composition of nontronite. Although data are limited, there are no obvious trends in $\mathrm{Pb}$ isotopic composition of the nontronites with increasing stratigraphic depth at mound sites.

2) The nontronite arrays are directed toward and closely approach the composition of average Mn nodules, which is considered representative of the $\mathrm{Pb}$ isotopic composition of seawater (average pelagic sediment also approximates the $\mathrm{Pb}$ isotopic composition of seawater).

3) Two nontronite samples have a very unusual isotopic composition, far more radiogenic than seawater (they are not included in the encircled arrays in Figs. 1 and 2).

4) The five pelagic sediment samples plot very closely together. Their average composition is slightly less radiogenic than average $\mathrm{Mn}$ nodules and average oceanic sediment. Brownish oxidized surface sediment (Sample 8 ) is somewhat less radiogenic than the average pelagic sediment in the Galapagos mounds area.
5) One sample, the Mn-Fe-oxide mud, has the composition of average $\mathrm{Mn}$ nodules and oceanic sediment.

6) One of the Mn-oxide crusts, from Hole 509B, is slightly less radiogenic than the average pelagic sediment of the Galapagos area and is in fact identical in composition to the sample of brownish oxidized surface sediment. The other Mn crust, from Hole 506C, plots near the middle of the nontronite array.

7) The basalts define approximately linear arrays which are mostly contained within the sediment arrays.

\section{Discussion}

The data on the nontronites (excluding Samples 13 and 17 , which will be discussed separately) can be interpreted as the result of mixing, in varying proportions, $\mathrm{Pb}$ derived from basaltic and seawater sources. The isotopic composition of the basement-derived $\mathrm{Pb}$ should be some average of the range in $\mathrm{Pb}$ isotopic composition displayed by individual basalt samples. The average proportion of this $\mathrm{Pb}$ to normal seawater $\mathrm{Pb}$ in the sedi-

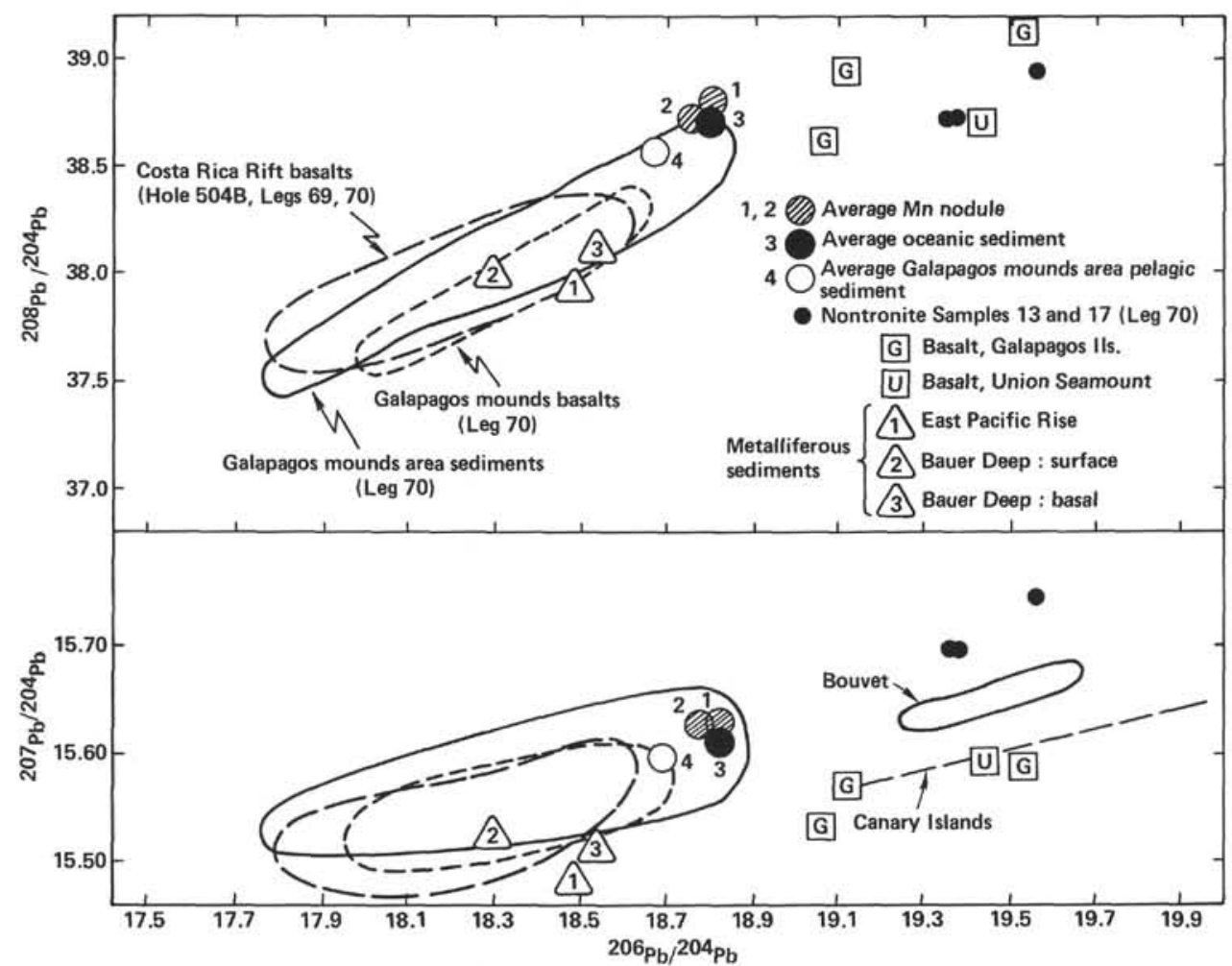

Figure 2. ${ }^{208} \mathrm{~Pb} /{ }^{204} \mathrm{~Pb}$ vs. ${ }^{206} \mathrm{~Pb} /{ }^{204} \mathrm{~Pb}$ and ${ }^{207} \mathrm{~Pb} /{ }^{204} \mathrm{~Pb}$ vs. ${ }^{206} \mathrm{~Pb} /{ }^{204} \mathrm{~Pb}$ for sediments and basalts from the Galapagos mounds area (Sites 506, 507 and 509; data from Fig. 1), and basalts from the Costa Rica Rift (Hole 504B, Barrett, Leg 69). Also shown are the average Pb isotopic compositions of Mn nodules (1: Reynolds and Dasch, 1971; 2: Stacey and Kramers, 1975), oceanic sediment (Stacey and Kramers, 1975), Galapagos mounds area pelagic sediment (average of Samples 6, 7, 9, 10, and 14, Table 1), and the compositions of three metalliferous sediments from the east Pacific (1: East Pacific Rise crest core V19-54, O'Nions et al., 1978; 2: Bauer Deep surface sediment, corrected value from Dasch et al., 1971, in Dymond et al., 1973; 3: Bauer Deep basal sediment [15 m.y. old]. Overlying tholeiite, DSDP Hole 319, Unruh and Tatsumoto, 1976). Nontronite Samples 12 and 17 (Fig. 1), three selected basalts from the Galapagos Island (White, 1979) and basalt from the Union Seamount (Church and Tatsumoto, 1975 ) are also shown in the upper and lower diagrams. The arrays of volcanic rocks from Bouvet and the Canary Islands (fig. 5, Sun et al., 1975) are plotted in the lower diagram. 
ment pore waters during the period of nontronite formation will then determine where the nontronitic $\mathrm{Pb}$ will plot on a mixing line. It is reasonable to expect that if the discharge rate of basement solutions through the mounds sediments is relatively high, normal seawater occupying the pore spaces will be gradually flushed out, and the nontronite will grow in the presence of solutions dominated by basaltic $\mathrm{Pb}$. It should be noted that basement-derived $\mathrm{Pb}$ could dominate sediment pore waters even if fairly substantial mixing with normal seawater takes place. For example, consider a volume of basalt which is leached by ten volumes of seawater. Leaching of $1 \%$ of the average amount of $\mathrm{Pb}$ in this basalt $(\sim 1$ ppm: Church and Tatsumoto, 1975; Unruh and Tatsumoto, 1976) would produce a concentration of $\mathrm{Pb}$ in basement solutions $\left(10^{-3} \mathrm{ppm}\right)$ at least one order of magnitude greater than the $\mathrm{Pb}$ concentration of normal seawater $\left(3 \times 10^{-5} \mathrm{ppm}\right.$ to $2 \times 10^{-6} \mathrm{ppm}$; Goldberg, 1965; C. C. Patterson, in Tatsumoto, 1978).

A Mn-oxide crust from Hole 509B (Sample 15) contains essentially seawater $\mathrm{Pb}$, although a small basaltic contribution is possible. (The uppermost nontronite in this hole [Sample 16], located only $50 \mathrm{~cm}$ below the analyzed $\mathrm{Mn}$-oxide crust, has an almost identical $\mathrm{Pb}$ isotopic composition.) By contrast, the other Mn-oxide crust (Sample 11) contains considerable basaltic $\mathrm{Pb}$. This indicates that Mn-oxide crusts, although formed at or near the surface of mounds, can also be influenced by basement-derived solutions during their growth.

Some Mn-oxide crusts are laminated on a millimeter scale, clearly visible in reflected light. Electron-microprobe analysis has shown that in one of the two cases investigated, layers with low $\mathrm{Pb}$ contents $(<100 \mathrm{ppm})$ are present together with occasional layers of high $\mathrm{Pb}$ content $(\sim 1000 \mathrm{ppm})$. Although errors of $\pm 100 \%$ can be expected for $\mathrm{Pb}$ contents of less than $200 \mathrm{ppm}$, the recorded variation is sufficient to indicate that it is real. The difference in $\mathrm{Pb}$-concentration suggests that the two types of layers have grown at different rates. Mn crusts which have grown in the presence of discharging hydrothermal solutions have very low $\mathrm{Pb}$ contents (generally $<20 \mathrm{ppm}$ ), and have grown relatively quickly (Toth, 1980). Manganese nodules and ferromanganese crusts forming in areas where bottom waters probably carry a hydrothermal component, such as on the East Pacific Rise and in the Bauer Deep (O'Nions et al., 1978; Dasch et al., 1971), typically contain 180 to 260 ppm $\mathrm{Pb}$ (Toth, 1980). By contrast, Mn nodules formed away from spreading axes as strictly hydrogenous deposits growing from normal seawater have very high $\mathrm{Pb}$ concentrations of 800 to $2500 \mathrm{ppm} \mathrm{Pb}$ (Mero, 1965; Toth, 1980). Galapagos mounds area Mn-oxide crusts have average $\mathrm{Pb}$ contents of about $56 \mathrm{ppm}$ (Moorby and Cronan, this volume), which is intermediate between the first two types of Mn deposit described above. It is possible that such crusts contain rapidly formed layers with a high isotopic component but low concentration of basaltic $\mathrm{Pb}$, and occasional more slowly formed layers with a relatively high isotopic component and high concentration of normal seawater $\mathrm{Pb}$. The net result would be a crust with a relatively low $\mathrm{Pb}$ content, but a predominantly seawater $\mathrm{Pb}$ isotopic composition. Crusts which are relatively enriched in basaltic $\mathrm{Pb}$, as in Sample 11 , would require a greater or perhaps more continuous influence from basement-derived solution.

Oxidized surface pelagic ooze (Sample 8, Hole 506B) has a $\mathrm{Pb}$ isotopic composition distinct from the typical pelagic sediments of the Galapagos mounds area, but identical to the Sample $15 \mathrm{Mn}$-oxide crust. It also differs from typical Galapagos pelagic ooze in containing a significantly higher concentration $(\sim 2 \%)$ of $\mathrm{Mn}$, mainly as micronodules. Possibly the small contribution of basaltic $\mathrm{Pb}$ in the oxidized ooze is associated in part with the $\mathrm{Mn}$ micronodules. Although no nontronite or $\mathrm{Mn}$ oxide fragments are present in this hole, it is situated only 50 meters from Hole 506, located on a mound. A small component of basement-derived solutions could conceivably be present in the pore waters of off-mound sites, and $\mathrm{Pb}$ could be precipitated with $\mathrm{Mn}$ as upwardmoving solutions pass through the oxidized surface layer.

$\mathrm{Mn}-\mathrm{Fe}$-oxide mud, found only as two 10 -cm-thick layers in Cores 1 and 2 of Hole 509B, is brownish black and has a rather gelatinous appearance. The ooze consists dominantly of black Mn-oxide microaggregates, with lesser amounts of orangish-brown microaggregates, which are probably $\mathrm{Fe}$ oxide-hydroxides. This is the only sample in which the $\mathrm{Pb}$ isotopic composition corresponds to the average seawater value, indicating no basaltic contribution. It is possible that the two $\mathrm{Mn}-\mathrm{Fe}$ mud layers formed at the sediment surface following discharge of $\mathrm{Mn}-\mathrm{Fe}$-rich solutions directly into seawater, rather than within the mound itself. Nevertheless, the absence of basaltic $\mathrm{Pb}$ is rather unexpected.

Two extraordinary $\mathrm{Pb}$ isotopic compositions were measured for nontronites from Core 507F-2 (Sample 13) and Core 509B-2 (Sample 17). These samples have not been included in the sediment array in Figure 1 because their $\mathrm{Pb}$ is too radiogenic to have been derived from midocean ridge basalts or seawater. A duplicate of Sample 17 , prepared by a different analyst in the same laboratory, produced identical results. Recently, a sample from $4 \mathrm{~cm}$ below Sample 13 yielded a $\mathrm{Pb}$ composition approximately intermediate between those of Samples 13 and 17 (P. Taylor, personal communication, 1981).

In Figure 2, the $\mathrm{Pb}$ isotopic compositions of selected oceanic basalts and sediments are shown, together with a summary of the data in Figure 1. The two radiogenic nontronite samples are also plotted. The only plausible source for such radiogenic $\mathrm{Pb}$ appears to be intraplate oceanic island volcanics. Some Galapagos Island basalts (the more radiogenic of those reported by White, 1979) have ${ }^{208} \mathrm{~Pb}$ and ${ }^{206} \mathrm{~Pb}$ isotopic compositions similar to those of the radiogenic nontronite samples. The ${ }^{207} \mathrm{~Pb}$ isotopic composition of these Galapagos Island basalts is, however, lower than that of the nontronite samples. The same observations can be made for a basalt sample from the Union Seamount in the northeast Pacific (Church and Tatsumoto, 1975). Easter Island volcanics (not shown) have a ${ }^{208} \mathrm{~Pb} / 204 \mathrm{~Pb}$ ratio quite similar to that of Sample 13, but both of the other isotopic ratios 
are lower (Tatsumoto, 1966). Island arc or continental margin arc volcanics are not likely to have supplied ash of the appropriate composition for either of Samples 13 and 17 , as such volcanics have ${ }^{206} \mathrm{~Pb} / 204 \mathrm{~Pb}$ ratios less than 19.1 (Doe and Stacey, 1974; Kay et al., 1978; McHugh, 1980).

Ocean island volcanics conceivably could be erupted as pyroclastic ash which could be transported by winds over long distances. Three ash layers, from 2 to $5 \mathrm{~cm}$ thick, have been found in Hole 158, located $550 \mathrm{~km}$ north of the Galapagos mounds area, at subsurface depths of 2, 15, and 20 meters (Yeats, 1973). Ash layers have been recorded from Hole 504B, Leg 69, $200 \mathrm{~km}$ east of the Galapagos mounds area, at subsurface depths of about 12 and 17 meters (the uppermost $10 \mathrm{~m}$ of sediment were not recovered) (J. Cann and M. Langseth, personal communication, 1981). In the Galapagos area, ash is present in Hole 509B at a depth of 6.3 meters, in Hole 507D at a depth of 6.5 meters and in Hole 509 at a depth of 12.0 meters. No ash was observed at depths shallower than 6.3 meters in Hole $509 \mathrm{~B}$ or 6.5 meters in Hole 507D; however, Mn-oxide-rich and nontronitic sediments occupy most of these intervals. The radiogenic nontronite from Hole 509B (Sample 17) occurs at a depth of approximately 3.5 meters, whereas the other radiogenic nontronite, from Hole 507F (Sample 13), is from a depth of 4.0 meters. (It should be noted that the exact depth of an ash layer deposited over a large area could vary significantly, depending on the local rate of pelagic sedimentation.)

The absence of recognizable ash in other sites in the mounds area could be the result of bioturbation, as it would be expected that ash layers (as in Hole 509B) which are deposited at least $300 \mathrm{~km}$ from the nearest probable source area also should be deposited at the other drilled sites, which are all located within $5 \mathrm{~km}$ of each other. Although no ocean island volcanic rocks have been reported in the literature with isotopic values matching perfectly those of the radiogenic nontronites (particularly with respect to the ${ }^{207} \mathrm{~Pb} /{ }^{204} \mathrm{~Pb}$ ratio), the only mechanism which at present can be invoked to explain their composition would seem to be replacement of an ocean island-derived ash band originally contained within pelagic sediment. This proposal could be tested by $\mathrm{Pb}$ isotopic analysis of ash bands from nearsurface sediments in the east Pacific.

The range in $\mathrm{Pb}$ isotopic composition of Galapagos mounds area sediments overlaps the basalt arrays from the mounds area and from the Costa Rica Rift (also part of the Galapagos spreading axis). Both the sediment and the basalt arrays are positioned slightly "higher" than some other midocean ridge basalts on the conventional isotopic plots (cf. Church and Tatsumoto, 1975; Tatsumoto, 1978).

\section{STRONTIUM ISOTOPES}

\section{Results and Discussion}

The ${ }^{87} \mathrm{Sr} /{ }^{86} \mathrm{Sr}$ ratios for five sediments and three basalts from the Galapagos mounds area are listed in Tables 1 and 2, respectively. One basalt from Site 510 was also analyzed.
Table 1. $\mathrm{Pb}$ and $\mathrm{Sr}$ isotopic composition of selected samples of nontronite, Mn-oxide crust, $\mathrm{Mn}-\mathrm{Fe}$-oxide mud, and pelagic sediments from the Galapagos mounds area, Leg 70 .

\begin{tabular}{|c|c|c|c|c|c|c|}
\hline $\begin{array}{l}\text { Sample } \\
\text { No. }\end{array}$ & $\begin{array}{l}\text { DSDP Sample } \\
\text { (interval in } \mathrm{cm} \text { ) }\end{array}$ & Lithology & $\frac{{ }^{206} \mathrm{~Pb}}{204 \mathrm{~Pb}}$ & $\frac{{ }^{207} \mathrm{~Pb}}{{ }^{204} \mathrm{~Pb}}$ & $\frac{{ }^{208} \mathrm{~Pb}}{{ }^{204} \mathrm{~Pb}}$ & $\frac{{ }^{87} \mathrm{Sr}}{{ }^{86} \mathrm{Sr}}$ \\
\hline 1 & $506-2-2,69-71$ & $\begin{array}{l}\text { Granular } \\
\text { nontronite }\end{array}$ & 18.405 & 15.597 & 38.030 & $0.70891 \pm 4$ \\
\hline 2 & $506-3-1,45-47$ & $\begin{array}{l}\text { Granular } \\
\text { nontronite }\end{array}$ & 17.836 & 15.532 & 37.569 & \\
\hline 3 & $506-4-2,45-47$ & $\begin{array}{l}\text { Granular } \\
\text { nontronite }\end{array}$ & 18.545 & 15.606 & 38.211 & \\
\hline 4 & $506-6-2,125-127$ & $\begin{array}{l}\text { Granular } \\
\text { nontronite }\end{array}$ & 18.244 & 15.569 & 38.039 & \\
\hline 5 & $506-6-3,39-41$ & $\begin{array}{l}\text { Foraminifer } \\
\text { nannofossil } \\
\text { ooze }\end{array}$ & 18.659 & 15.608 & 38.455 & \\
\hline 6 & $506-8-1,86-88$ & $\begin{array}{l}\text { Foraminifer } \\
\text { nannofossil } \\
\text { ooze }\end{array}$ & 18.663 & 15.579 & 38.427 & $0.70909 \pm 5$ \\
\hline 7 & $506 \mathrm{~B}-1-1,21-23$ & $\begin{array}{l}\text { Diatomaceous } \\
\text { nannofossil } \\
\text { ooze }\end{array}$ & 18.539 & 15.606 & 38.356 & \\
\hline 8 & $506 \mathrm{~B}-2-3,12-14$ & $\begin{array}{l}\text { Foraminifer } \\
\text { diatom nan- } \\
\text { nofossil } \\
\text { ooze }\end{array}$ & 18.700 & 15.595 & 38.522 & \\
\hline 9 & 506B-5-1, 94-96 & $\begin{array}{l}\text { Foraminifer } \\
\text { nannofossil } \\
\text { ooze }\end{array}$ & 18.706 & 15.623 & 38.406 & \\
\hline 10 & $506 C-2-1,67-69$ & $\begin{array}{l}\text { Mn-oxide } \\
\text { crust }\end{array}$ & 18.273 & 15.545 & 37.984 & \\
\hline 11 & $506 \mathrm{C}-4-3,40-42$ & $\begin{array}{l}\text { Compact } \\
\text { nontronite }\end{array}$ & 18.731 & 15.607 & 38.516 & \\
\hline $12 \mathrm{a}$ & $507 \mathrm{D}-2-1,52-54$ & $\begin{array}{l}\text { Granular } \\
\text { nontronite }\end{array}$ & 18.791 & 15.584 & 38.453 & \\
\hline $12 \mathrm{~b}$ & Duplicate & & 18.776 & 15.576 & 38.416 & \\
\hline 13 & $507 \mathrm{~F}-2-2,6-8$ & $\begin{array}{l}\text { Granular } \\
\text { nontronite }\end{array}$ & 19.563 & 15.752 & 38.917 & \\
\hline 14 & $507 F-7-1,77-79$ & $\begin{array}{l}\text { Foraminifer } \\
\text { nannofossil } \\
\text { ooze }\end{array}$ & 18.647 & 15.573 & 38.420 & \\
\hline 15 & $509 \mathrm{~B}-1-2,85-90$ & $\begin{array}{l}\text { Mn-oxide } \\
\text { crust }\end{array}$ & 18.564 & 15.620 & 38.310 & $0.70908 \pm 6$ \\
\hline 16 & $509 \mathrm{~B}-1-2,133-135$ & $\begin{array}{l}\text { Granular } \\
\text { nontronite }\end{array}$ & 18.540 & 15.598 & 38.223 & \\
\hline $17 \mathrm{a}$ & $509 \mathrm{~B}-2-1,44-48$ & $\begin{array}{l}\text { Granular } \\
\text { nontronite }\end{array}$ & 19.358 & 15.699 & 38.722 & $0.70909 \pm 4$ \\
\hline $17 \mathrm{~b}$ & Duplicate & & 19.376 & 15.691 & 38.718 & \\
\hline 18 & $509 \mathrm{~B}-2-1,114-118$ & $\begin{array}{l}\text { Mn-Fe-oxide } \\
\text { mud }\end{array}$ & 18.790 & 15.633 & 38.651 & $0.70896 \pm 7$ \\
\hline 19 & 509B-3-1, 100-102 & $\begin{array}{l}\text { Granular } \\
\text { nontronite }\end{array}$ & 18.536 & 15.584 & 38.173 & \\
\hline 20 & $509 \mathrm{~B}-4-3,37-39$ & $\begin{array}{l}\text { Granular } \\
\text { nontronite }\end{array}$ & 18.124 & 15.570 & 37.920 & \\
\hline
\end{tabular}

In the case of the sediments, the pelagic ooze, the Mn crust, and one of the nontronites (Sample 17, $3.5 \mathrm{~m}$ subsurface) have identical ${ }^{87} \mathrm{Sr} /{ }^{86} \mathrm{Sr}$ ratios of 0.70909 , 0.70908 , and 0.70909 . These values are equivalent to the ${ }^{87} \mathrm{Sr} /{ }^{86} \mathrm{Sr}$ ratios of modern seawater $(0.70910 \pm 6$; Veizer and Compston, 1974). The ${ }^{87} \mathrm{Sr} /{ }^{86} \mathrm{Sr}$ ratio for the $\mathrm{Mn}$-oxide ooze is just marginally lower, while the ratio for the other nontronite (Sample 2, 6.5 m subsurface) is 0.70891 . This latter value appears to be statistically distinguishable from seawater and would imply an $\sim 3 \%$ contribution of basaltic $\mathrm{Sr}$ to the nontronite, given an average initial ${ }^{87} \mathrm{Sr} /{ }^{86} \mathrm{Sr}$ ratio for fresh basalt of 0.70265 (see below).

It should be noted that the reason a given nontronite or manganiferous sediment can contain a distinct basaltic $\mathrm{Pb}$ component, but only seawater-derived $\mathrm{Sr}$, is related to the relative abundances of these elements in seawater and basalt. Although the basalts contain two orders of magnitude more $\mathrm{Sr}$ than $\mathrm{Pb}(\sim 120 \mathrm{ppm}$ vs. $\sim 1$ ppm, Hart, 1976; Yamaguchi et al., 1977; Church and Tatsumoto, 1975; Unruh and Tatsumoto, 1976), seawater contains about six orders of magnitude more $\mathrm{Sr}$ than $\mathrm{Pb}\left(\sim 8 \mathrm{ppm}\right.$ vs. $3 \times 10^{-5}$ to $2 \times 10^{-6} \mathrm{ppm}$, Veizer and Compston, 1974; Goldberg, 1965; C. C. Pat- 
Table 2. $\mathrm{Pb}-, \mathrm{Sr}$ - and $\mathrm{O}$-isotopic compositions, and $\mathrm{Rb}$ and $\mathrm{Sr}$ contents of basalts from the Galapagos mounds area, Leg 70.

\begin{tabular}{|c|c|c|c|c|c|c|c|c|c|c|}
\hline $\begin{array}{c}\text { Sample } \\
\text { No }\end{array}$ & $\begin{array}{l}\text { DSDP Sample } \\
\text { (interval in cm) }\end{array}$ & Lithology & Alteration ${ }^{\mathrm{a}}$ & $\frac{{ }^{206} \mathrm{~Pb}}{{ }^{204} \mathrm{~Pb}}$ & $\frac{{ }^{207} \mathrm{~Pb}}{{ }^{204} \mathrm{~Pb}}$ & $\frac{{ }^{208} \mathrm{~Pb}}{204 \mathrm{~Pb}}$ & $\begin{array}{c}\mathrm{Rb} \\
(\mathrm{ppm})\end{array}$ & $\begin{array}{c}\mathrm{Sr} \\
(\mathrm{ppm})\end{array}$ & $\frac{{ }^{87} \mathrm{Sr}^{\mathrm{b}}}{{ }^{86} \mathrm{Sr}}$ & $\delta^{18} \mathrm{O}$ \\
\hline 1 & $\begin{array}{l}\text { 506G-2-1, 30-33 } \\
\text { (Piece 4) }\end{array}$ & $\begin{array}{l}\text { Fine-grained sparsely Pl- } \\
\text { Cpx phyric basalt; mar- } \\
\text { gin of pillow }\end{array}$ & G & 18.187 & 15.520 & 37.763 & 0.6 & 60.4 & $0.70275 \pm 5$ & 5.8 \\
\hline 2 & $\begin{array}{l}\text { 507B-1,1, 46-50 } \\
\text { (Piece 24) }\end{array}$ & $\begin{array}{l}\text { Coarse-grained subophitic } \\
\text { basalt; thin flow ( } \sim 50 \\
\mathrm{~cm}) \text { thick; sample from } \\
\text { middle }\end{array}$ & Nil & 18.621 & 15.578 & 38.097 & 0.3 & 63.6 & $0.70256 \pm 5$ & 5.9 \\
\hline 3 & $507 \mathrm{~F}-9, \mathrm{CC}$ & $\begin{array}{l}\text { Glass fragments, presu- } \\
\text { mable from pillow mar- } \\
\text { gin }\end{array}$ & Nil & 18.366 & 15.532 & 38.018 & 1.3 & 59.6 & - & 5.7 \\
\hline 4 & $\begin{array}{c}\text { 508B-4-1, 3-6 } \\
\text { (Piece 44) }\end{array}$ & $\begin{array}{l}\text { Fine-grained aphyric ba- } \\
\text { salt; probably margin } \\
\text { of pillow }\end{array}$ & G & 18.348 & 15.565 & 37.904 & 4.1 & 60.0 & $0.70278 \pm 7$ & - \\
\hline
\end{tabular}

a $\mathrm{G}=$ greenish to brownish to near-colorless smectites replacing olivine and glass, and as vesicle fillings.

b Average ${ }^{87} \mathrm{Sr} /{ }^{66} \mathrm{Sr}$ for samples 1, 2, 4 and 5: 0.70268. Errors are 2 standard errors of the mean. Average $\mathrm{Rb}$ and $\mathrm{Sr}$ values for all 5 samples are

$1.1 \mathrm{ppm}$ and $58.2 \mathrm{ppm}$, respectively.

terson, in Tatsumoto, 1978). A given volume of discharging solution which had leached (or isotopically exchanged with) $1 \%$ of the $\mathrm{Sr}$ and $\mathrm{Pb}$ from an equal volume of basement would contain $\sim 1 \mathrm{ppm}$ basaltic $\mathrm{Sr}$ and $\sim 0.01 \mathrm{ppm}$ basaltic $\mathrm{Pb}$. Mixture with an equal volume of normal seawater (or even 10 volumes of seawater) would then produce a solution dominated by seawater $\mathrm{Sr}$ and basaltic $\mathrm{Pb}$.

The four analyzed basalts have tightly grouped ${ }^{87} \mathrm{Sr} /$ ${ }^{86} \mathrm{Sr}$ ratios ranging from values of 0.70256 to 0.70278 , with a mean of 0.70268 (Table 2). The range is outside of analytical error and may be the result of limited amounts of primary magmatic variation and/or limited seawater alteration. The mean value of 0.70268 is, however, almost indistinguishable from the mean value for fresh midocean ridge basalts of 0.70265 (Hart, 1976). The basalts also have tightly grouped oxygen isotope ratios, with a mean $\delta^{18} \mathrm{O}$ value of $5.8 \pm 0.1 \%$ (Table 2 ). This value is statistically indistinguishable from the average value for fresh midocean ridge basalts of $5.8 \pm$ $0.3 \%$ (Taylor, 1968; Muehlenbachs and Clayton, 1972). The Sr- and O-isotopic data, taken together, indicate that the analyzed samples have not been affected isotopically by seawater contamination during low-temperature alteration. Therefore, the overall water/rock ratio must have been very low. By contrast, basalts recovered by the DSDP from oceanic crust of age 3.5 to $110 \mathrm{~m}$.y. typically show $\mathrm{Sr}$ - and $\mathrm{O}$-isotopic evidence of seawater alteration (cf. Yamaguchi et al., 1977; Gray et al., 1977; Hoernes and Friedrichsen, 1979; Hoernes et al., 1979; Muehlenbachs, 1979; Staudigel et al., 1979). The virtual lack of isotopic alteration of the three mounds area basalts is rather surprising, given the fact that the area represents sites of discharging/recharging solutions which have circulated through the underlying basement. One reason may be that the circulation zones are very localized, for example along certain basement fractures; the drilled sites could have been slightly removed from these zones. Another factor may be related to the young age of the basalts. The basalts in the Galapagos mounds area are less than $1 \mathrm{~m}$.y. old, and could conceivably undergo future isotopic alteration. Convective seawater circulation within the basaltic basement on the Costa Rica Rift is known to continue for up to about 5 m.y. (Anderson and Hobart, 1976).

\section{SUMMARY}

The $\mathrm{Pb}$ isotopic compositions of metalliferous sediments from the Galapagos mounds area define approximately linear arrays in conventional isotopic ratio plots. The arrays, which result mainly from variation in the $\mathrm{Pb}$ isotopic composition of nontronite, overlap the fields defined by basalts from the Galapagos mounds area and the Costa Rica Rift and are directed toward and closely approach the average $\mathrm{Pb}$ isotopic composition of $\mathrm{Mn}$ nodules. These relations indicate that the metalliferous sediments formed from solutions which contained variable proportions of basaltic $\mathrm{Pb}$, introduced into pore waters by basement-derived solutions, and of normal seawater $\mathrm{Pb}$.

Two nontronite samples have highly radiogenic $\mathrm{Pb}$ isotopic compositions which are not readily explained; a possibility may be that they represent the alteration products of volcanic ash, derived from an oceanic island. A sample of $\mathrm{Mn}$-Fe-oxide mud contains only seawater $\mathrm{Pb}$. One $\mathrm{Mn}$-oxide crust and an oxidized surface pelagic ooze appear to contain a small contribution of basaltic $\mathrm{Pb}$, while a second $\mathrm{Mn}$-oxide crust contains a significant component of basaltic $\mathrm{Pb}$.

The $\mathrm{Sr}$ isotopic compositions of the metalliferous and pelagic sediments from the Galapagos mounds area are essentially indistinguishable from the value for modern seawater. The ${ }^{87} \mathrm{Sr} /{ }^{86} \mathrm{Sr}$ ratios of four basalts from subbasement depths of $<15$ meters display a small range of 0.70256 to 0.70278 with an average of 0.70268 , almost identical to the average value of 0.70265 for fresh midocean ridge basalts. Oxygen isotope ratios of four Galapagos area basalts have a mean $\delta^{18} \mathrm{O}$ value of $5.8 \pm$ 
$0.1 \%$, also characteristic of fresh midocean ridge basalts. The $\mathrm{Sr}$ - and $\mathrm{O}$-isotopic data indicate that the overall water/rock ratio within the uppermost basalts has been very limited.

\section{ACKNOWLEDGMENTS}

I would like to thank Dr. S. Moorbath for permission to use the isotope laboratory at Oxford, Mr. Roy Goodwin (Oxford) for preparation of six $\mathrm{Pb}$ samples, Mr. Clive Johnson (Oxford) for preparation of the Sr samples, and Dr. C. J. Bray for technical assistance. Dr. P. Taylor provided useful advice on mass spectrometer operation. Drs. E. T. C. Spooner (Toronto), A. H. F. Robertson (Edinburgh), and P. Taylor (Oxford) reviewed an earlier version of the manuscript and made numerous helpful suggestions. This research was supported by the Natural Sciences and Engineering Research Council of Canada.

\section{REFERENCES}

Anderson, R. N., and Hobart, M. A., 1976. The relation between heat flow, sediment thickness, and age in the eastern Pacific. $J$. Geophys. Res., 81:2968-2989.

Arden, J. W., and Gale, N. H., 1974. New electrochemical technique for the separation of lead at trace levels from natural silicates. Anal. Chem., 46:2-8.

Bender, M., Broecker, W., Gornitz, V., Middel, U., Kay, R., Sun, S. -S., and Biscaye, P., 1971. Geochemistry of three cores from the East Pacific Rise. Earth Planet. Sci. Lett., 12:425-433.

Bischoff, J. L., 1969. Red Sea geothermal brine deposits: Their mineralogy, chemistry and genesis. In Degons, E. T. (Ed.), Recent Heavy Metal Deposits in the Red Sea: New York (SpringerVerlag), pp. 368-401.

Bischoff, J. L., and Dickson, F. W., 1975. Seawater-basalt interaction at $200 \mathrm{C}$ and 500 bars: implications for origin of seafloor heavy-metal deposits and regulation of seawater chemistry. Earth Planet. Sci. Lett., 25:385-397.

Boström, K., 1973. The origin and fate of ferromanganoan active ridge sediments. Stockholm Contrib. Geol., 27(2):149-243.

Boström, K., and Fisher, D. E., 1971. Volcanogenic uranium, vanadium and iron in Indian Ocean sediments. Earth Planet. Sci. Lett., 11:95-98.

Boström, K., Joensuu, O., Valdés, S., Charm, W., and Glaccum, R., 1976. Geochemistry and origin of East Pacific sediments sampled during DSDP Leg 34. In Yeats, R. S., Hart, S. R., et al., Init. Repts. DSDP, 34: Washington (U.S. Govt. Printing Office), 559-574.

Boström, K., Joensuu, O., Valdés, S., and Riera, M., 1972. Geochemical history of South Atlantic Ocean sediments since Late Cretaceous. Mar. Geol., 12:85-121.

Cann, J. R., Winter, C. K., and Pritchard, R. G., 1977. A hydrothermal deposit from the floor of the Gulf of Aden. Mineral. Mag., 41:193-199.

Church, S. E., and Tatsumoto, M., 1975. Lead isotope relations in oceanic ridge basalts from the Juan de Fuca-Gorda Ridge area, N. E. Pacific Ocean. Contrib. Min. Pet., 53:253-279.

Clayton, R. N., and Mayeda, R. K., 1963. The use of bromine pentafluoride in the extraction of oxygen from oxides and silicates for isotopic analysis. Geochim. Cosmochim. Acta, 27:43-52.

Corliss, J. B., 1971. The origin of metal-bearing submarine hydrothermal solutions. J. Geophys. Res., 76:8128-8138.

Corliss, J. B., Dymond, J., Gordon, L. E., Edmond, J. M., Von Herzen, R. P., Ballard, R. D., Green, K., Williams, D., Bainbridge, A. E., Crane, K., and van Andel, Tj. H., 1979. Submarine thermal springs on the Galapagos Rift. Science, 203:1073-1083.

Corliss, J. B., Lyle, M., and Dymond, J., 1978. The chemistry of hydrothermal mounds near the Galapagos Rift. Earth Planet. Sci. Lett., 40:12-24.

Cumming, G. L., 1976. Lead isotope ratios in DSDP Leg 37 basalts. Can. J. Earth Sci., 31:179-183.

Dasch, E. J., Dymond, J. R., and Heath, G. R., 1971. Isotopic analysis of metalliferous sediment from the East Pacific Rise. Earth Planet. Sci. Lett., 13:175-180.

Doe, B. R., and Stacey, J. S., 1974. The application of lead isotopes to problems of ore genesis and ore prospect evaluation: A review. Econ. Geol., 69:757-776.
Dymond, J., Corliss, J. B., Heath, G. R., Field, C. W., Dasch, E. J., and Veeh, H. H., 1973. Origin of metalliferous sediments from the Pacific Ocean. Geol. Soc. Am. Bull., 84:3355-3372.

Edmond, J. M., Measures, C., Mangum, B., Grant, B., Sclater, F. R., Collier, R., and Hudson, A., 1979. On the formation of metalrich deposits at ridge crests. Earth. Planet. Sci. Lett., 46:19-30.

Goldberg, E. D., 1965. The minor constituents of seawater. In Riley, J. P., and Skirrow, G. (Eds.), Chemical Oceanography, (Vol. 1): New York (Academic Press), 163-196.

Gray, J., Cumming, G. L., and Lambert, R. St J., 1977. Oxygen and strontium isotopic compositions and thorium and uranium contents of basalts from DSDP cores. In Aumento, F., Melson, W. G., et al., Init. Repts. DSDP, 37: Washington (U.S. Govt. Printing Office), 607-609.

Hart, S. R., 1976. LIL-element geochemistry, Leg 34 basalts. In Yeats, R. S., Hart, S. R., et al., Init. Repts. DSDP, 34: Washington (U.S. Govt. Printing Office), 283-288.

Heath, G. R., and Dymond, J., 1977. Genesis and transformation of metalliferous sediments from the East Pacific Rise, Bauer Deep, and Central Basin, Northwest Nacza Plate. Geol. Soc. Am. Bull., 88:723-733.

Hoernes, S., and Friedrichsen, F., 1979. ${ }^{18} \mathrm{O} /{ }^{16} \mathrm{O}$ and D/H investigations on basalts of Leg 46. In Dmitriev, L., Heirtzler, J., et al., Init. Repts. DSDP, 46: Washington (U.S. Govt. Printing Office), 253-255.

Hoernes, S., Friedrichsen, H., and Schock, H. H., 1979. Oxygen- and hydrogen-isotope and trace-element investigations on rocks of DSDP Hole 395A, Leg 45. In Melson, W. G., Rabinowitz, P. D., et al., Init. Repts. DSDP, 45: Washington (U.S. Govt. Printing Office), 541-550.

Hoffert, M., Perseil, A., Hekinian, R., Choukroune, P., Needham, H. D., Francheteau, J., and Le Pichon, X., 1978. Hydrothermal deposits sampled by diving saucer in Transform Fault "A" near $37^{\circ} \mathrm{N}$ on the Mid-Atlantic Ridge, FAMOUS area. Oceanolog. Acta, 1:73-86.

Horowitz, A., and Cronan, D. S., 1976. The geochemistry of basal sediments from the North Atlantic Ocean. Mar. Geol., 20:205-228.

Kay, R. W., Sun, S.-S., and Lee-Hu, C.-N., 1978. Pb and Sr isotopes in volcanic rocks from the Aleutian Islands and Pribilof Islands, Alaska. Geochim. Cosmochim. Acta, 42:263-273.

Lalou, C., Brichet, E., Ku, T. L., and Jahanno, C., 1977. Radiochemical, scanning electron microscope (SEM) and X-ray dispersive energy (EDAX) studies of a FAMOUS hydrothermal deposit. Mar. Geol., 24:245-258.

McHugh, J., 1980. Lead isotope studies and the origin of calc-alkaline igneous rocks in the Andes of South America. [M. Sc. dissert.]. Oxford University, p. 86.

Mero, J. L., 1965. The Mineral Resources of the Sea: Amsterdam (Elsevier).

Moore, W. S., and Vogt, P. R., 1976. Hydrothermal manganese crusts from two sites near the Galapagos spreading axis. Earth Planet. Sci. Lett., 29:349-356.

Muehlenbachs, K., 1979. Alteration and aging of the basaltic crust of the sea floor. In Donnelly, T., Francheteau, J., Bryan, W., Robinson, P., Flower, M., Salisbury, M., et al., Init. Repts. DSDP, 51, 52, 53, Pt. 2: Washington (U.S. Govt. Printing Office), 1159-1167.

Muehlenbachs, K., and Clayton, R. N., 1972. Oxygen isotope studies of fresh and weathered basalts. Can. J. Earth Sci., 9:172-184.

O'Nions, R. K., Carter, S. R., Cohen, R. S., Euensen, N. M., and Hamilton, P. J., 1978. $\mathrm{Pb}, \mathrm{Nd}$ and $\mathrm{Sr}$ isotopes in oceanic ferromanganese deposits and ocean floor basalts. Nature, 273: 435-438.

O'Nions, R. K., and Pankhurst, R. J., 1973. Determination of Rb/ $\mathrm{Sr}$ and ${ }^{87} \mathrm{Sr} /{ }^{86} \mathrm{Sr}$ ratios of some standard rocks and evaluation of $\mathrm{X}$-ray fluorescence spectrometry in $\mathrm{Rb}-\mathrm{Sr}$ geochemistry. Chem. Geol., 12:127-136.

Reynolds, P. H., and Dasch, E. J., 1971. Lead isotopes in marine Mn nodules and the ore-lead growth curve. J. Geophys. Res., 76: 5124-5128.

Scott, M. R., Scott, R. B., Rona, P. R., Butler, L. W., and Nalwalk, A. J., 1974. Rapidly accumulating manganese deposits from the median valley of the Mid-Atlantic Ridge. Geophys. Res. Lett., 1: 355-358.

Spooner, E. T. C., and Fyfe, W. S., 1973. Sub-seafloor metamorphism, heat and mass transfer. Contrib. Min. Pet., 42:287-304. 


\section{T. J. BARRETT}

Stacey, J. S., and Kramers, J. D., 1975. Approximation of terrestrial lead isotope evolution by a two-stage model. Earth Planet. Sci. Lett., 26:207-221.

Staudigel, H., Frey, F. A., and Hart, S. R., 1979. Incompatible traceelement geochemistry and ${ }^{87} \mathrm{Sr} /{ }^{86} \mathrm{Sr}$ in basalts and corresponding glasses and palagonites. In Donnelly, T., Francheteau, J., Bryan, W., Robinson, P., Flower, M., and Salisbury, M., et al., Init. Repts. DSDP, 51, 52, 53, pt. 2: Washington (U.S. Govt. Printing Office), 1137-1145.

Sun, S-S., Tatsumoto, M., and Schilling, J-G., 1975. Mantle plume mixing along the Reykjanes Ridge axis: Lead isotope evidence. Science, 190:143-147.

Tatsumoto, M., 1966. Genetic relations of oceanic basalts as indicated by lead isotopes. Science, 153:1094-1101.

1978. Isotopic composition of lead in oceanic basalt and its implication to mantle evolution. Earth Planet. Sci. Lett., 38:63-87.

Taylor, H. P., Jr., 1968. The oxygen isotope geochemistry of igneous rocks. Contrib. Mineral, Petrol., 19:1-71.
Toth, J. R., 1980. Deposition of submarine crusts rich in manganese and iron. Geol. Soc. Am. Bull., 91:44-54.

Unruh, D. M., and Tatsumoto, M., 1976. Lead isotopic composition and uranium, thorium, and lead concentrations in sediments and basalts from the Nazca Plate. In Yeats, R. S., Hart, S. R., et al. Init. Repts. DSDP, 34: Washington (U.S. Govt. Printing Office), 341-347.

Veizer, J., and Compston, W., 1974. ${ }^{87} \mathrm{Sr} /{ }^{86} \mathrm{Sr}$ composition of sea water during the Phanerozoic. Geochim. Cosmochim. Acta, 38: 1461-1484.

Yamaguchi, M., Armstrong, R. L., Russell, R. D., and Slawson, W. F., 1977. Strontium and lead isotopic investigations of igneous rocks from the Mid-Atlantic Ridge: DSDP, Leg 37. In Aumento, F., and Melson, W. G., et al., Init. Repts. DSDP, 37: Washington (U.S. Govt. Printing Office), 613-616.

Yeats, R. S., 1973. Volcanic ash: Leg 16, Deep Sea Drilling Project. In van Andel, Tj. H., Heath, G. R., et al., Init. Repts. DSDP, 16: Washington (U.S. Govt. Printing Office), 615.

White, W. M., 1979. Pb isotope geochemistry of the Galapagos Islands. Carn. Inst. Washington Y. B., 78:331-335. 